\title{
Influence of arbuscular mycorrhizal fungi and Trichoderma viride on growth performance of Salvia officinalis Linn.
}

\author{
Aditya Kumar*,Ashok Aggarwal and Sunita Kaushish \\ Department of Botany, Kurukshetra University, Kurukshetra - 136119 (Haryana), INDIA \\ *Corresponding author. E-mail: adityagohar@yahoo.com
}

\begin{abstract}
Salvia officinalis (Sage) is a popular kitchen herb, member of mint (Lamiaceae) family has been cultivated for its wide range of medicinal values. Arbuscular mycorrhizae (AM) are beneficial symbionts for plant growth and development and offer a viable replacement of high input agricultural technology employed for production of environmentally hazardous fertilizers. Therefore, the present study was focused to analyze the effect of two AM fungi (Acalospora laevis and Glomus mosseae) along with Trichoderma viride, alone and in combination, on different growth parameters of S.officinalis in a green house pot experiment with sterilized soil. AM inoculum and T.viride showed significant increase of different growth parameters after 45 and 90 days of inoculation. Among all treatments, dual combination of A.laevis plus T.viride was most effective in increasing shoot length, leaf area, root length, root weight, AM spore number and percent root colonization. Moreover, maximum increase in shoot biomass was found in plant treated with T.viride.
\end{abstract}

Keywords : Salvia officinalis, Acaulospora laevis, Glomus mosseae, Trichoderma viride, Growth response.

\section{INTRODUCTION}

Salvia officinalis Linn. is a evergreen sub- shrub and has been used traditionally for its anti inflammation, antidyspepsia, antioxidant, hypoglycemic properties and mutagenic activities (Wang, 1998; Baricevic and Bartol, 2000). Modern day clinical trials have shown that its essential oil can improve the memory and has shown promise in the treatment of Alzheimer's disease (Akhondzadeh and Abbasi, 2006).

Since the plant has a great significance due to its wide range of the therapeutic potential to treat a large number of ailments, it becomes necessary to enhance their biomass production and their quality in order to fulfill the need of society. Therefore, it requires formulation of planning and strategies for their conservation and enhancement of its products. However, the outputs are limited because of low level of fertilizer used and of the care taken to harvest. It is therefore advisable to develop cheaper solution, such as the mycorrhizal inoculation. The AM fungi are known to colonize a number of tropical plants including vegetables (Reddy et al., 2006).

Arbuscular mycorrhizal fungi are now a day well recognized as biofertilizers (Bohra et al., 2007), biological control of root pathogens (Reddy et al., 2006), bioremediation (Li et al., 2006), increase in biomass of plant (Kumar et al., 2008; Karthikeyan et al., 2008), nutrient content (Das et al., 2007) and drought tolerance (Farahani et al., 2008). Hence, in the present study, analysis has been made to see the effect of AM fungi (A.laevis and G.mosseae) and T.viride, alone and in dual combination, on different growth parameters of S.officinalis after 45 and 90 days of inoculation.

\section{MATERIALS AND METHODS}

Study Site: The study was undertaken in poly house of Botany Department, Kurukshetra University, Kurukshetra, India.

Sample collection and processing : Soil samples from the root zone of S.officinalis were collected to a depth of 5-30 $\mathrm{cm}$. The soil samples were wet- sieved for spores using the technique of Gerdemann and Nicolson (1963) and quantification of AM spores was done by grid line intersect method (Adholeya and Gaur,1994). Root samples were rinsed with tap water and cut into $1 \mathrm{~cm}$. pieces and performed with trypan blue according to rapid clearing and staining method of Philips and Haymann (1970). The percent AM root colonization was calculated by using the following formula:

Total no. of root segments colonized Percent AM root colonization $=\longrightarrow \times 100$

Total no. of root segments examined

Mass multiplication and inoculation of AM spores and T.viride : Dominant AM spores i.e. Acaulospora laevis and Glomus mosseae isolated from rhizosphere of S.officinalis, were mass produced by Funnel technique 
(Menge and Timmer, 1982) using maize as host. T.viride was isolated from the soil and then further mass produced in the medium of wheat bran, saw dust and distilled water prepared in the ratio of 3:1:4 (Sharma et al., 2007).

Moreover, seedlings of S.officinalis were grown in earthen pots (Size $25 \times 25$ ) under poly house conditions in sterilized soil. To each pot $10 \%$ of inoculum of AM fungi and T.viride alone and in combination was added. The effects of different treatments were recorded after 45 and 90 days of inoculation on various growth parameters. Roots and shoots were harvested and weighted separately for their fresh weight and the oven dried to $70^{\circ} \mathrm{C}$ for dry weight. Leaf area was studied using leaf area meter (Systronics 211) and stomatal conductance was observed by using porometer (AP4-Delta T devices,UK). Statistical analysis was performed using one-way analysis of variance (ANOVA) followed by post hoc test.

\section{RESULTS AND DISCUSSION}

Shoot length: AM inoculation significantly increased the shoot length of S.officinalis after 45 and 90 days. Increase in shoot length was maximum in dual inoculation of A.laevis plus T.viride (Table-1). This shows the efficacy of AM fungus and T.viride on growth of S.officinalis. Artursson et al. (2006) reported the synergestic effect of dual inoculation of AM fungi and Trichoderma on plant growth through a mechanism that includes nutrient absorption and inhibition of plant pathogens. Significant increment in height after 45 and 90 days of inoculation could be attributed to the AM colonization as it known to enhance plant growth by nutrient uptake and secreting plant growth hormones. The increase in height could be due to the greater rate of photosynthesis (Allen et al., 1981). Kungiu et al. (2008) reported the progressive increase in shoot length of Senna spectabilis with AM inoculation.

Shoot biomass: It is envisaged from Table-1, the plants inoculated with T.viride showed highest biomass. This may be due to increased uptake of inorganic nutrients via increased absorbing surface by inoculated plants and can be due to maximum branched shoots of this plant as compared to other treatments. The efficacy of Trichoderma for plant growth promotion may be due to higher nutrient uptake particularly N,P,K,Fe, $\mathrm{Zn}$ and $\mathrm{Cu}$ in several crops including sugarcane (Shukla et al., 2008; Howell, 2003). Trichoderma are known to produce a number of antibiotics such as trichodermin, trichodermol, polyketides, peptaiboils, sesquterpenes and steroids. They are frequently associated with both biocontrol activity and promotion of plant and root growth (Chet et al., 2006, Harman et al., 2004). The stimulated growth with Trichoderma inoculation has also been reported on tomato
(Ozbay et al., 2004) and on Nicotiana benthamiana (Charon et al., 2007).

Root length: Table 1 indicates that the maximum increase in root length was found in dual inoculation of A.laevis plus T.viride. Perrin(1990) found that mycorrhizal inoculation protects the roots from soil pathogens and tends to increase growth of roots. The maximum increase in root length might be due to mycelial network of AM fungi which extends deeper to invade nutrient depletion zone. Kumar et al. (2008) while working on Spilanthes acmella, reported the maximum increase in root length when inoculated with AM fungi and Trichoderma viride. Significant increase in root length with AM fungi have also been reported by Reddy et al. (2006) and Akhtar and Siddique (2007).

Leaf area: AM inoculation significantly increased the leaf area of all treated plant as compared to control plant (Table1). It was found that after 45 days of inoculation the leaf area was found maximum in the plant treated with T.viride and 90 days after inoculation (DAI) the maximum increase in leaf area was recorded in the treatment of A.laevis plus T.viride. Higher leaf area in AM inoculated plant might be as a result of enhanced nitrogen acquisition (Tobar et al., 1994b) by host plant through the external hyphal transport of $\mathrm{NO}_{3}$ (Tobar et al., 1994a) or nitrogen assimilating enzymes(Cliquet and Stewart, 1993). The increase of leaf area with AM inoculation would be beneficial by maintaining a higher photosynthetic rate (Auge et al., 1987; Panwar, 1993). A positive effect of leaf area to AM inoculation has been also reported in Sesame (Boureima et al., 2007) and Sorghum (Ebel et al., 1994).

Root biomass: The result (Table-1) show that the amount of root biomass has been found to be increased progressively irrespective of treatment over control. The increase in root biomass (fresh and dry) was observed maximum with of T.viride after 45 days. After 90 days the increase in fresh root biomass was found maximum with A.laevis plus T.viride but the dry root weight was found maximum with G.mosseae plus T.viride. The increase in fresh root weight in inoculated plants could be either with increased mycorrhizal colonization or due to the formation of external mycelial network around the roots by AM fungi. The results are in agreement with the findings of earlier investigators (Karthikeyan et al., 2008; Gupta and Janardhanan, 1991) who observed improved root biomass production in different plants due to AM fungi inoculation.

AMSpore count and Mycorrhizal colonization: The status of spore population and degree of mycorrhizal infection was also studied under different treatments and result depicted in Table-1 showed that the mycorrhizal spore count was found maximum in plants inoculated with A.laevis plus T.viride and highest AM root colonization 
Table-1. Influence of Arbuscular mycorrhizal fungi and T. viride on growth performance of S. officinalis after 45days and 90 days.

\begin{tabular}{|c|c|c|c|c|c|c|c|c|c|c|}
\hline Treatment & $\begin{array}{l}\text { Change in } \\
\text { height } \\
\text { (cm) }\end{array}$ & $\begin{array}{l}\text { Leaf area } \\
(\mathrm{sq} \mathrm{cm})\end{array}$ & $\begin{array}{l}\text { Root } \\
\text { length } \\
\text { (cm) }\end{array}$ & $\begin{array}{l}\text { Fresh shoot } \\
\text { weight } \\
\text { (g) }\end{array}$ & $\begin{array}{l}\text { Dry shoot } \\
\text { weight } \\
\text { (g) }\end{array}$ & $\begin{array}{l}\text { Fresh root } \\
\text { weight } \\
\text { (g) }\end{array}$ & $\begin{array}{l}\text { Dry root } \\
\text { weight } \\
\text { (g) }\end{array}$ & $\begin{array}{l}\text { AM spore } \\
\text { number } / 10 \text { g o } \\
\text { soil }\end{array}$ & $\begin{array}{l}\text { AM root } \\
\text { colonization } \\
(\%)\end{array}$ & $\begin{array}{l}\text { Stomatal } \\
\text { conductivity } \\
\left(\mathrm{mmol}^{-2} \mathrm{~s}^{-2}\right)\end{array}$ \\
\hline \multicolumn{11}{|c|}{ After 45 Days } \\
\hline Control & $* 8.23 \pm 0.15$ & $2.06 \pm 0.60$ & $9.56 \pm 0.32$ & $2.28 \pm 0.01$ & $0.44 \pm 0.02$ & $0.51 \pm 0.06$ & $0.16 \pm 0.02$ & $22.33 \pm 4.72$ & $22.47 \pm 0.61$ & $\begin{array}{ll}\mathrm{L} & 15.7 \pm 0.81 \\
\mathrm{U} & 4.1 \pm 0.25\end{array}$ \\
\hline $\begin{array}{l}\text { Trichoderma } \\
\text { viride }\end{array}$ & $14.03 \pm 0.20$ & $5.30 \pm 0.50$ & $12.60 \pm 0.10$ & $4.98 \pm 0.01$ & $1.50 \pm 0.05$ & $1.89 \pm 0.02$ & $0.53 \pm 0.02$ & $34.33 \pm 1.52$ & $28.86 \pm 1.26$ & $\begin{array}{ll}\mathrm{L} & 58.3 \pm 0.79 \\
\mathrm{U} & 13.3 \pm 0.40\end{array}$ \\
\hline $\begin{array}{l}\text { Glomus } \\
\text { mosseae }\end{array}$ & $17.1 \pm 0.26$ & $2.96 \pm 0.20$ & $12.06 \pm 0.15$ & $2.55 \pm 0.10$ & $0.92 \pm 0.08$ & $1.06 \pm 0.02$ & $0.23 \pm 0.05$ & $30.0 \pm 2.0$ & $39.76 \pm 1.50$ & $\begin{array}{ll}\mathrm{L} & 92.66 \pm 0.61 \\
\mathrm{U} & 21.9 \pm 0.20\end{array}$ \\
\hline $\begin{array}{l}\text { Acaulospora } \\
\text { laevis }\end{array}$ & $16.56 \pm 0.20$ & $3.76 \pm 0.15$ & $11.66 \pm 0.35$ & $2.85 \pm 0.05$ & $1.19 \pm 0.07$ & $1.08 \pm 0.01$ & $0.36 \pm 0.02$ & $44.66 \pm 2.51$ & $46.23 \pm 0.90$ & $\begin{array}{lr}\mathrm{L} & 78.2 \pm 0.20 \\
\mathrm{U} & 25.3 \pm 0.37\end{array}$ \\
\hline $\begin{array}{l}\text { A.laevis+ } \\
\text { G.mosseae }\end{array}$ & $15.56 \pm 0.15$ & $4.23 \pm 0.70$ & $12.93 \pm 0.15$ & $2.66 \pm 0.18$ & $0.78 \pm 0.05$ & $0.92 \pm 0.04$ & $0.31 \pm 0.02$ & $52.33 \pm 1.52$ & $54.51 \pm 0.60$ & $\begin{array}{ll}\mathrm{L} & 54.03 \pm 0.15 \\
\mathrm{U} & 23.1 \pm 0.25\end{array}$ \\
\hline $\begin{array}{l}\text { G.mosseae+ } \\
\text { T.viride }\end{array}$ & $21.86 \pm 0.37$ & $4.20 \pm 0.10$ & $14.46 \pm 0.20$ & $3.88 \pm 0.11$ & $1.41 \pm 0.02$ & $1.54 \pm 0.03$ & $0.39 \pm 0.02$ & $62.33 \pm 1.52$ & $69.1 \pm 0.96$ & $\begin{array}{ll}\mathrm{L} & 104.9 \pm 0.15 \\
\mathrm{U} & 26.66 \pm 0.20\end{array}$ \\
\hline $\begin{array}{l}\text { A.laevis+ } \\
\text { T.viride }\end{array}$ & $23.46 \pm 0.45$ & $4.30 \pm 0.70$ & $17.03 \pm 0.41$ & $4.89 \pm 1.03$ & $1.48 \pm 0.02$ & $1.62 \pm 0.02$ & $0.49 \pm 0.01$ & $78.0 \pm 3.0$ & $60.2 \pm 1.90$ & $\begin{array}{ll}\mathrm{L} & 96.1 \pm 0.35 \\
\mathrm{U} & 21.0 \pm 0.20 \\
\end{array}$ \\
\hline \multicolumn{11}{|c|}{ After 90 Days } \\
\hline Control & $* 14.1 \pm 0.26$ & $2.50 \pm 0.20$ & $11.3 \pm 0.2$ & $4.54 \pm 0.81$ & $1.33 \pm 0.03$ & $0.62 \pm 0.09$ & $0.21 \pm 0.01$ & $46.0 \pm 2.0$ & $30.0 \pm 1.75$ & $\begin{array}{ll}\mathrm{L} & 24.33 \pm 0.40 \\
\mathrm{U} & 7.34 \pm 0.12\end{array}$ \\
\hline $\begin{array}{l}\text { Trichoderma } \\
\text { viride }\end{array}$ & $15.96 \pm 0.30$ & $5.33 \pm 1.30$ & $13.53 \pm 0.20$ & $12.74 \pm 1.0$ & $3.91 \pm 1.06$ & $2.62 \pm 0.11$ & $0.63 \pm 0.02$ & $52.66 \pm 1.52$ & $37.96 \pm 1.41$ & $\begin{array}{ll}\mathrm{L} & 72.8 \pm 0.1 \\
\mathrm{U} & 27.4 \pm 0.15\end{array}$ \\
\hline $\begin{array}{l}\text { Glomus } \\
\text { mosseae }\end{array}$ & $18.4 \pm 0.26$ & $4.1 \pm 0.43$ & $14.36 \pm 0.15$ & $7.84 \pm 0.11$ & $1.45 \pm 0.05$ & $1.25 \pm 0.09$ & $0.35 \pm 0.01$ & $65.0 \pm 1.0$ & $42.66 \pm 0.25$ & $\begin{array}{ll}\mathrm{L} & 118.03 \pm 0.30 \\
\mathrm{U} & 39.7 \pm 0.25\end{array}$ \\
\hline $\begin{array}{l}\text { Acaulospora } \\
\text { laevis }\end{array}$ & $29.65 \pm 0.35$ & $4.63 \pm 0.30$ & $14.83 \pm 0.25$ & $8.50 \pm 0.59$ & $2.89 \pm 0.02$ & $1.22 \pm 0.01$ & $0.44 \pm 0.02$ & $57.0 \pm 1.0$ & $51.93 \pm 0.25$ & $\begin{array}{ll}\mathrm{L} & 107.4 \pm 0.25 \\
\mathrm{U} & 36.9 \pm 0.20\end{array}$ \\
\hline $\begin{array}{l}\text { A.laevis+ } \\
\text { G.mosseae }\end{array}$ & $22.7 \pm 0.26$ & $4.33 \pm 0.64$ & $18.4 \pm 0.26$ & $4.56 \pm 0.55$ & $2.52 \pm 0.01$ & $1.13 \pm 0.04$ & $0.34 \pm 0.01$ & $79.66 \pm 1.52$ & $57.02 \pm 1.52$ & $\begin{array}{ll}\mathrm{L} & 102.6 \pm 0.26 \\
\mathrm{U} & 35.1 \pm 0.32\end{array}$ \\
\hline $\begin{array}{l}\text { G.mosseae+ } \\
\text { T.viride }\end{array}$ & $31.8 \pm 1.85$ & $4.63 \pm 0.83$ & $18.93 \pm 0.35$ & $8.56 \pm 0.77$ & $2.60 \pm 0.02$ & $2.10 \pm 0.01$ & $0.71 \pm 0.02$ & $92.0 \pm 2.0$ & $74.5 \pm 2.09$ & $\begin{array}{ll}\mathrm{L} & 131.6 \pm 0.40 \\
\mathrm{U} & 45.06 \pm 0.25\end{array}$ \\
\hline $\begin{array}{l}\text { A.laevis+ } \\
\text { T.viride }\end{array}$ & $35.3 \pm 1.21$ & $5.6 \pm 0.25$ & $19.93 \pm 0.45$ & $6.36 \pm 0.13$ & $2.25 \pm 0.06$ & $3.02 \pm 0.07$ & $0.67 \pm 0.03$ & $101.66 \pm 5.03$ & $82.3 \pm 3.21$ & $\begin{array}{ll}\mathrm{L} & 128.06 \pm 0.35 \\
\mathrm{U} & 39.3 \pm 0.45\end{array}$ \\
\hline
\end{tabular}

According to one way analysis of variance (ANOVA) of data, the mean difference is significant at 0.05 levels., * Each value is an average of three replicates \pm Standard deviation, L-Lower surface, U-Upper surface 
was found in the dual combination of Gmosseae plus T.viride after 45 days and in A.laevis plus T.viride after 90 days respectively. Griffee and Metha (2000) and Earanna et al. (2001) reported a positive response in respect to spore count and root colonization while working on Catharanthus roseus and Coleus aromaticus respectively. The increase in AMF spore population could be due to enhanced spread of AM fungal hyphae as reported by Muthukumar and Udaiyan (2002) and Koomen et al. (1987). The plant under different treatments also showed the AM association, which confirms the host dependency on endomycorrhizae. Similar was the assessment of Arshi and Roy (2008) in Gliricidia sepium.

Stomatal conductance: Mycorrhizal colonization of roots also influences the stomatal behaviour of leaves. Stomatal conductance increased when inoculated with different combination of AM fungi and T.viride. Result depicted in Table 1 showed that the dual interaction of G.mosseae plus T.viride significantly increased the stomatal conductance in S.officinalis. The progressive increase in stomatal conductance in AM inoculation might be due to higher photosynthetic rate and number of stomata on lower surface of leaf. Higher rate of stomatal conductance in mycorrhizal plants have also been reported by Auge (2001). Fidelbus et al. (2001) also reported positive role of AM fungi on citrus seedlings when exposed to severe soil drying by lowering the rate of leaf conductivity.

The tremendous advances in research on mycorrhizal physiology and ecology over the past 40 years have led to a greater understanding of the multiple roles of AMF in the ecosystem. Therefore, in the present investigation, the efficacy of two strains of AM fungi along with T.viride was analyzed on different growth parameters of S.officinalis. As mycorrhizal symbiosis is a highly evolved mutualistic relationship for plant establishment, so this study provides a great future for utilizing the efficient strains of mycorrhizal fungi to exploit them for the beneficial effects in establishment of seedlings, increase in productivity and reduce the fertilizer application required for obtaining economic production of S.officinalis plant under field conditions.

\section{ACKNOWLEDGEMENT}

The author (AK) is highly grateful to Kurukshetra University, Kurukshetra, Haryana for financial assistance in the form of university research scholarship.

\section{REFERENCES}

Adholeya, A. and Gaur, A. (1994). Estimation of VAM fungal spores in soil. Mycorrhiza News, 6(1): 10-11.

Akhondzadeh, S. and Abbasi, S.H. (2006). Herbal medicine in the treatment of Alzheimer disease. Pam. J. Alzheimers Dis other Deman, 21: 113-118.
Akhtar, M.S. and Siddiqui, Z.A. (2007). Biocontrol of a chickpea root- rot disease complex with Glomus intraradices, Pseudomonas putida and Paenibacillus polymyxa. Austra. Plant Path., 36(2): 175-180.

Allen, M.F., Smith, W.K., Moore, T.S. and Chiristensen, M. (1981). Comparitive water relation and photosynthesis of mycorrhizal and non-mycorrhizal Bouteluoa gracilis H.B.K. New Phytol., 88:683-693.

Arshi, A. and Roy, A.K. (2008). Effect of vermicompost and endomycorrhizae on growth performance of Gliricidia sepium (Jaco. Kunth.) on overburden dump soil of coal field area. $J$. Indian Bot. Soc., 87(3-4): 178-181.

Artursson, V., Finlay, R.D. and Jansson, J.K. (2006). Interactions between AMF and bacteria and their potential for stimulating plant growth. Env. Microbiol., 8(1): 1-10.

Auge, R.M. (2001). Water relations, drought and vesicular arbuscular mycorrhizal symbiosis. Mycorrhiza, 11: 3-42.

Auge, R.M., Schekel, K.A. and Wample, R.L. (1987). Rose leaf elasticity changes in response to mycorrhizal colonization and drought acclimation. Physiol. Plant., 70: 175-182.

Baricevic, D. and Bartol, T. (2000). The biological/ pharmacological activity of the Salvia genus. In: S.E. Kintzios (Ed.), SAGE- The genus Salvia (pp 143-184). Amsterdam, The Netherlands: Harwood Academic Publishers.

Bohra, A., Mathur, N., Bohra, S., Singh, J. and Vyas, A. (2007). Influence of AM fungi on physiological changes in Terminalia arjuna L.: An endangered tree of Indian thar desert. Indian Forester, 133(11): 1558-1562.

Boureima, S., Diouf, M., Diop, T.A., Datta, M., Leye, E.M., Ndiaye, F. and Seck, D. (2007). Effects of arbuscular mycorrhizal inoculation on the growth and the development of sesame (Sesamum indicum L.) African journal of Agricultural Research, 3(3): 234-238.

Charon, M.R., Rodriguez- Galan, O., Benitez, T., Sousa, S., Rey, M., Liobell, A. and Delgado- Jarana, J. (2007). Transcriptose analysis of early colonization of tomato roots by Trichoderma harzianum. Microbiology, 10(1): 19-27.

Chet, I., Viterbo, A., Brotman, Y. and Lousky, T. (2006). Enhancement of plant disease resistance by biocontrol agent Trichoderma. Life Science. URL:http:// www.weizmann.ac.il/

Cliquet, J.B. and Stewart, G.R. (1993). Ammonia assimilation in maize infected with an AM fungus Glomus fasciculatum. Plant Physiol., 101: 865-871.

Das, K., Dang, R., Shivananda, T.N. and Sekeroglu, N. (2007). Influence of bio-fertilizers on biomass yield and nutrient content in Stevia rebaudiana Bert. grown in Indian subtropics. Journal of Medicinal Plants Research, 1(1): 005-008.

Earanna, N., Mallikarjuniah, R.R., Bagyaraj, D.J., and Suresh, C.K. (2001). Response of Coleus aromaticus to Glomus fasciculatum and other beneficial soil microflora. Journal of Spices and Aromatic Crops, 10(2): 141-143.

Ebel, R.C., Stodola, A.J.W., Duan, X. and Augé, R.M. (1994). Nonhydraulic root-to shoot signaling in mycorrhizal and nonmycorrhizal sorghum exposed to partial soil drying or root severing. New Phytol., 127: 495-506.

Farahani, A., Lebaschi, H., Hussein, M., Hussein, S.A., Reza, V.A. and Jahanfar, D. (2008). Effects of arbuscular mycorrhizal fungi, different levels of phosphorus and drought stress on water use efficiency, relative water content and proline 
accumulation rate of Coriander (Coriandrum sativum L.). Journal of Medicinal Plants Research, 2(6): 125-131.

Fidelbous, M.W., Martin, C.A. and Stutz, J.C. (2001). Geographic isolates of Glomus increase root growth and whole- plant transpiration of citrus seedlings growth with high phosphorus. Mycorrhiza, 10: 231-236.

Gerdemann, J. W. and Nicolson, Y. H. (1963). Spores of mycorrhizae Endogone species extracted from soil by wet seiving and decanting. Trans. Brit. Mycol. Soc., 46: 235-244.

Griffee, P. and Metha, S. (2000). Organic production of medicinal, aromatic and dye yielding plants (MADPS) with inputs. New Delhi: FRLHT Publications.

Gupta, M.L. and Janardhanan, K.K. (1991). Mycorrhizal association of Glomus aggregatum with Palmarosa enchances, growth and biomass. Plant and Soil, 131: 261264.

Harman, G.E., Howell, C.R., Viterbo, A., Chet, I. and Iorito, M. (2004). Trichoderma species- opportunistic, avirulent plant symbionts. Nature Microbiol Rev., 2: 43-56.

Howell, C.R. (2003). Mechanism employed by Trichoderma species in the biological control of plant disease, the history and evolution of current concepts. Plant Dis., 87: 4-10.

Karthikeyan, B., Jaleel, C.A., Changxing, Z., Joe, M.M., Srimannarayan, J. and Deiveekasundaram, M. (2008). The effect of AM fungi and phosphorus level on the biomass yield and ajmalicine production in Catharanthus roseus. EurAsia J BioSci., 2: 26-33.

Koomen, J., Grace, C. and Hayman, D.S. (1987). Effectiveness of single and multiple mycorrhizal inocula on growth of clover and strawberry plants at two soil pHs. Biochem. 19: 539544.

Kumar, A., Aggarwal, A., Sharma, S. and Kaushish, S. (2008). Interaction of Arbuscular mycorrhizal fungi and Trichoderma viride on growth of Spilanthes acmella Murr. J. Indian Bot. Soc., 87(1-2): 120-124.

Kungiu, J.B., Lasco, R.D., Dela Cruz, L.U., Dela Cruz, R.E. and Husain, T. (2008). Effect of vesicular arbuscular mycorrhiza (VAM) fungi inoculation on coppicing ability and drought resistance of Senna spectabilis. Pak.J.Bot., 40(5): 2217-2224.

Li, Q., Ling, W., Gao, Y., Li, F. and Xiong, W. (2006). Arbuscular mycorrhizal bioremediation and its mechanism of organic pollutants- contaminated soils. Ying Yong Sheng Tai Xue Bao., 17(11): 2217-2221.
Menge, J.A. and Timmer, L.W. (1982). Procedure for inoculation of plants with VAM in the laboratory, greenhouse and field. In: N.C. Schenck (Ed.), Methods and Principles of Mycorrhizal Research (pp 59). St.Pauls, USA: American Phytopathology Society.

Muthukumar, T. and Udaiyan, K. (2002). Growth and yield of cowpea as influenced by changes in AM in response to organic manuring. J.Agron. Crop Sci., 188(2): 123-132.

Ozbay, N., Newman, S.E. and Brown, W.M. (2004). The effect of Trichoderma harzianum strains in the growth of tomato seedlings. Proc. Xxvi. IHC Manage, Acta Hort. 635: 131135 .

Panwar, J.D.S. (1993). Effect of VAM and Azospirillum on growth and yield of wheat. Indian J. Plant Physiol., 34: 357361 .

Perrin, R. (1990). Interactions between mycorrhizae and diseases caused by soil borne fungi. Soil Use Manage., 6: 198-195.

Philips, J. M. and Hayman, D. S. (1970). Improved procedures for clearing roots and staining parasitic and VAM fungi for rapid assessment of infection. Trans. Brit. Mycol. Soc., 55: 158-161.

Reddy, B.N., Raghanender, C.R. and Sreevani,A. (2006). Approach for enhancing mycorrhiza mediated disease resistance of tomato damping off. Indian Phytopath., 59(3): 299-304.

Sharma, S., Aggarwal, A. and Kaushish, S. (2007). Effect of two arbuscular mycorrhizal fungi on the growth of Stevia rebaudiana Bertoni. J. Indian Bot. Soc., 86(3-4): 100-104.

Shukla, S.K., Yadav, R.L., Suman, A. and Singh, P.N. (2008). Improving rhizospheric environment and sugarcane ratoon yield through bioagent amendment farm yard manure in udic ustrochrept soil. Soil \& Tillage Research., 2480: 1-11.

Tobar, R., Azcon, R. and Barea, J.M. (1994a). Improved nitrogen uptake and transport from $15 \mathrm{~N}$-lebelled nitrate by external hyphae of arbuscular mycorrhizae under water stressed conditions. New Phytol., 126: 119-122.

Tobar, R., Azcon, R. and Barea, J.M. (1994b). The improvement of plant $\mathrm{N}$ acquisition from an ammonium-treated, droughtstressed soil by the fungal symbiot in arbuscular mycorrhizae. Mycorrhiza 4: 105-108.

Wang, M., Li, J., Rangarajan, M., Shao, Y., LaVoie, E.J., Huang, T.C. and Ho, C.T. (1998). Antioxidative phenolic compounds from sage (Salvia officinalis). Journal of Agricultural and Food Chemistry, 46: 4869-4873. 